\title{
Saudi Arabia and the emergence of a novel coronavirus
}

Z.A. Memish, ${ }^{1}$ R. Alhakeem ${ }^{7}$ and G.M. Stephens ${ }^{7}$

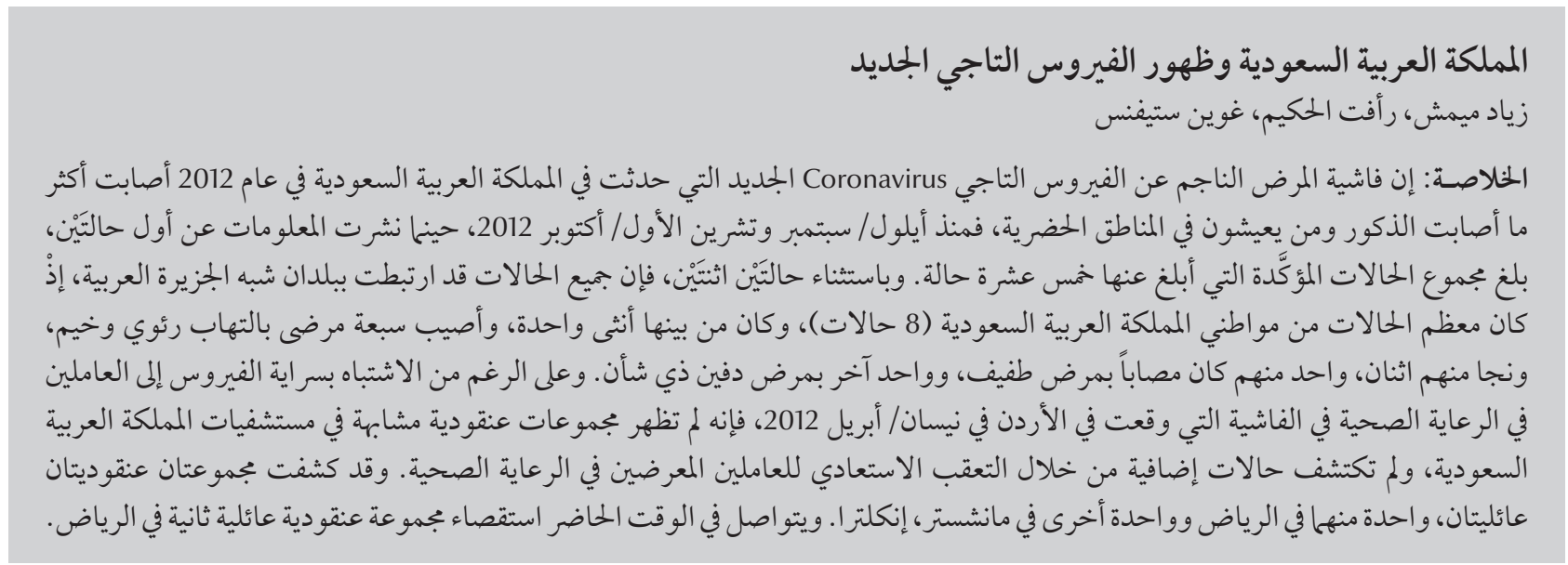

ABSTRACT The novel coronavirus disease outbreak in Saudi Arabia in 2012 predominately affected males and those living in urban areas. Since September and October 2012, when the first 2 cases were published, a total of 15 confirmed cases have been reported. All but 2 have been linked to countries of the Arabian peninsula; Saudi Arabian nationals accounted for a majority, 8 in all, and only 1 case was female. Seven patients had severe pneumonia; 2 survived -1 with mild disease and 1 with significant underlying illness. Although transmission of the virus to health-care workers was suspected in Jordan's April 2012 outbreak, similar clusters have not been found in Saudi Arabia's hospitals, nor have additional cases been identified through retrospective tracing of exposed health-care workers. Two family clusters have been identified, 1 in Riyadh and 1 in Manchester, England. A second Riyadh family cluster is being investigated.

\section{Emergence d'un nouveau coronavirus en Arabie saoudite}

RÉSUMÉ La flambée d'une infection par le nouveau coronavirus en Arabie saoudite en 2012 a principalement affecté des hommes et des résidents urbains. Depuis septembre et octobre 2012, lorsque les deux premiers cas ont été rendus public, 15 cas confirmés au total ont été notifiés. Tous les cas sauf deux avaient des liens avec des pays de la Péninsule arabique ; les citoyens saoudiens étaient majoritaires avec huit cas et un seul cas de sexe féminin a été observé. Sept patients ont souffert d'une pneumonie sévère ; deux ont survécu, le premier cas étant atteint d'une forme légère de la maladie et le deuxième cas étant porteur d'une maladie sous-jacente importante. Si la transmission du virus aux agents de soins de santé a été suspectée pendant la flambée d'avril 2012 en Jordanie, aucun groupe similaire n'a été observé dans les hôpitaux en Arabie saoudite ; aucun cas supplémentaire n'a été dépisté après le suivi rétrospectif des agents de soins de santé exposés. Deux groupes familiaux ont été identifiés, un à Riyad et un autre à Manchester (Angleterre). Un deuxième groupe familial fait l'objet d'analyses à Riyad. 


\section{Introduction}

Novel coronavirus ( $\mathrm{nCoV}$ ) was first isolated in June 2012 from the respiratory secretions of a businessman in the Bisha area of Saudi Arabia, who subsequently died of pneumonia and renal failure [1]. This discovery, published in September 2012 [2], was accompanied by a full genome sequence deposit and development of commercial laboratory tests for diagnosing acute cases [3]. Confirmation of more cases of $\mathrm{nCoV}$ infection followed, including the case of a Qatari national who had been transported to London for treatment of severe pneumonia [4], and another Saudi Arabian case, a middle-aged teacher in Riyadh, who was the first to survive the infection [5]. The sequencing alignments for the 2 viral genes from these first 3 cases were identical, and confirmed the outbreak of a virulent new coronavirus in the Arabian peninsula [5]. Although there was no immediate evidence of similar illness in the hospital contacts or family contacts of any of these confirmed cases, the clinical presentations were similar to that of severe acute respiratory syndrome (SARS) pneumonia, prompting the Saudi Arabian government to convene a session of its National Scientific Council to address this new communicable disease risk both for the local population and for inbound Hajj pilgrims, who were already arriving by the tens of thousands at King Abdulaziz international airport and other Saudi Arabian ports of entry.

\section{Background}

The 2003 SARS epidemic had galvanized global efforts to improve and modernize communicable disease surveillance, and to identify and contain outbreaks of serious respiratory disease as a first priority. Although influenza preparedness programmes had been updated in many jurisdictions by the year 2000 , it was a previously unknown human coronavirus that emerged in southern China during the winter of 2002 that would highlight the inherent weaknesses of solitary national efforts. Before SARS disappeared the following summer, it had made more than 8000 people ill and killed 774 in some 30 countries. It had also disrupted international trade and compromised the economies of more than a dozen affected jurisdictions, in developed and developing countries alike. The World Health Organization (WHO) followup response included an update of its 1969 International Health Regulations in 2005 [6], modifications of treaty obligations that would improve member state accountability and a reorganization that prioritized global surveillance and reporting through the Global Outbreak Alert and Response network. The emergence of another $\mathrm{nCoV}$ in the Eastern Mediterranean Region is about to test these systems.

\section{Cases and laboratory investigations}

The publichealth directorate of the Ministry of Health $(\mathrm{MOH})$ in Saudi Arabia is charged with policy and planning for communicable diseases prevention and control. In September 2012 its surveillance and investigation mandates were expanded to identify nCoV cases as a priority, assess transmission to close contacts and investigate the possibility that this was a new zoonotic infectious disease with an animal reservoir on the Arabian peninsula.

\section{Case finding}

Acutely ill individuals who met Saudi Arabia's case definition (Table 1) were identified through physician, infection control and other institutional reports to the $\mathrm{MOH}$ communicable diseases office. Hospitals and medical cities were required to identify patients on ventilation to the $\mathrm{MOH}$ and submit specimens for testing. Specimens submitted for influenza surveillance were screened for $\mathrm{nCoV}$. Hospital laboratories were also required to add $\mathrm{nCoV}$ to routine investigations of respiratory illness cases. Specimens found to be positive by initial testing at $\mathrm{MOH}$ laboratories were forwarded for confirmation to the United Kingdom (UK) Health Protection Agencylaboratories in Birmingham and Colindale, England, where they were assayed for coinfecting viruses (influenza $A$ and $B$ virus, parainfluenza virus, respiratory syncytial virus, adenovirus, human metapneumovirus and seasonal coronaviruses). $\mathrm{nCoV}$ confirmation was done by molecular amplification of $3 \mathrm{nCoV}$ genes. Confirmation results were reported to the $\mathrm{MOH}$ and by the country's focal point to WHO.

\section{Chart reviews}

Chart reviews were done for each case to identify clinical features, evaluate comorbidities and risk factors and track the case response to treatment.

\section{Family investigations}

Epidemiologists investigated cases and associated households within their respective administrative jurisdictions. Investigations included a survey of the immediate premises, household interviews and evaluations of close contacts, in particular family caregivers. Swabs and sera were collected and coded for each family member.

\section{Infection control investigations}

Hospitals and medical cities conducted retrospective investigations according to institutional protocols. Swabs and sera were collected by infection control personnel, coded and referred to the $\mathrm{MOH}$ laboratories.

\section{Animal studies}

Surveillance of immediate and neighbouring premises was done for each case, along with investigations of adjoining areas and locales such as rest houses (istirahat) and farms that had 


\begin{tabular}{|c|c|}
\hline Term & Saudi Arabian criteria \\
\hline Suspected case & $\begin{array}{l}\text { - Acute respiratory illness; } \\
\text { - Onset includes high fever } \geq 38{ }^{\circ} \mathrm{C} \text {, cough; } \\
\text { - Requires hospitalization; } \\
\text { - Evidence of lung parenchymal involvement; } \\
\text { - Not explained by other etiology. }\end{array}$ \\
\hline Probable case & $\begin{array}{l}\text { - May or may not require hospitalization but otherwise fits criteria for suspected } \\
\text { case; } \\
\text { - Specimens are not available for testing or patient is not available for testing; } \\
\text { - Not explained by other etiology. }\end{array}$ \\
\hline Confirmed case & - Laboratory confirmed. \\
\hline Close contact & $\begin{array}{l}\text { - Anyone who provided care for the patient; } \\
\text { - May include health-care worker or family member; } \\
\text { - Anyone who stayed in the same place as a probable or confirmed case while } \\
\text { case was symptomatic. }\end{array}$ \\
\hline Hajj case definition & $\begin{array}{l}\text { - Meets criteria for suspected, probable or confirmed case; } \\
\text { - Symptom onset during Hajj, or } 10 \text { days before or } 10 \text { days after Hajj; } \\
\text { - Located in or near Mecca or Medina cities. }\end{array}$ \\
\hline Secondary case & $\begin{array}{l}\text { - Contact with a suspected, probable or confirmed case; } \\
\text { - Disease onset within } 10 \text { days of index case. }\end{array}$ \\
\hline
\end{tabular}

been visited by cases. This was used to guide specimen collections that were forwarded to reference laboratories for sequencing studies.

\section{Summary of findings}

\section{Confirmed cases}

Table 2 summarizes the chronology and clinical picture of cases linked to Saudi Arabia. To date, Saudi Arabia has had a total of 8 confirmed cases, including 2 survivors - 1 who did not progress to respiratory failure and 1 who survived despite underlying disease and respiratory and renal failure. Only 1 confirmed case was female, the others were males between the ages of 31 and 70 years. The 5 sporadic cases outnumbered the 3 cases in clusters, although a second family cluster linked to case 15 was identified. All but 2 cases lived in urban Riyadh: case 1 resided in Bisha, an agricultural community located in south-western Asir province, and case 14 lived in Burayda, a city in Al Qassim province, north of Riyadh (Figure 1).

\section{Suspected cases}

In addition to the 8 confirmed cases, Saudi Arabia to date has had 2 suspected cases, both residents of Riyadh. The first was a 16-year-old male, grandson of case 7 , son of case 8 and nephew of case 9. All were members of the same household. A second suspected case was the brother of case 15 and the likely index case for his household. Case 10, a 60-year-oldUKresident with a history of travel to Pakistan and Saudi Arabia, was reported by the UK Health Protection Agency on 7 February 2013. This case was also associated with subsequent transmission of novel coronavirus to 2 family members, neither of whom had travelled outside the UK [7].

\section{Surveillance before, during and after Hajj}

\section{Background}

The Hajj pilgrimage draws 2.5 to 3 million visitors to Saudi Arabia each year, more than half of whom come from overseas countries. Planning for each gathering involves the work of 24 supervising committees that coordinate with the Saudi Arabian $\mathrm{MOH}$ as the agency with primary oversight of preventive medicine and public health matters. Pilgrims are provided with free health care in 141 centres in or near Hajj venues. This includes 25 hospitals and a total of 4457 beds including 500 critical care and 500 emergency care beds. Around 20000 specialized healthcare workers are deployed to work in these various facilities in a typical year. Ports of entry are managed by public health officers to ensure compliance with $\mathrm{MOH}$ regulations. There are additional public health teams, including 21 mobile teams, located in various areas of the Hajj. King Abdulaziz international airport terminal in Jeddah is the port of entry for more than $80 \%$ of pilgrims and the site of initial health screening for the vast majority who will enter the holy sites within hours to days of arriving in Saudi Arabia. Public health teams based at the airport and throughout Hajj venues report to a central unit on 9 types of communicable disease: influenza and 


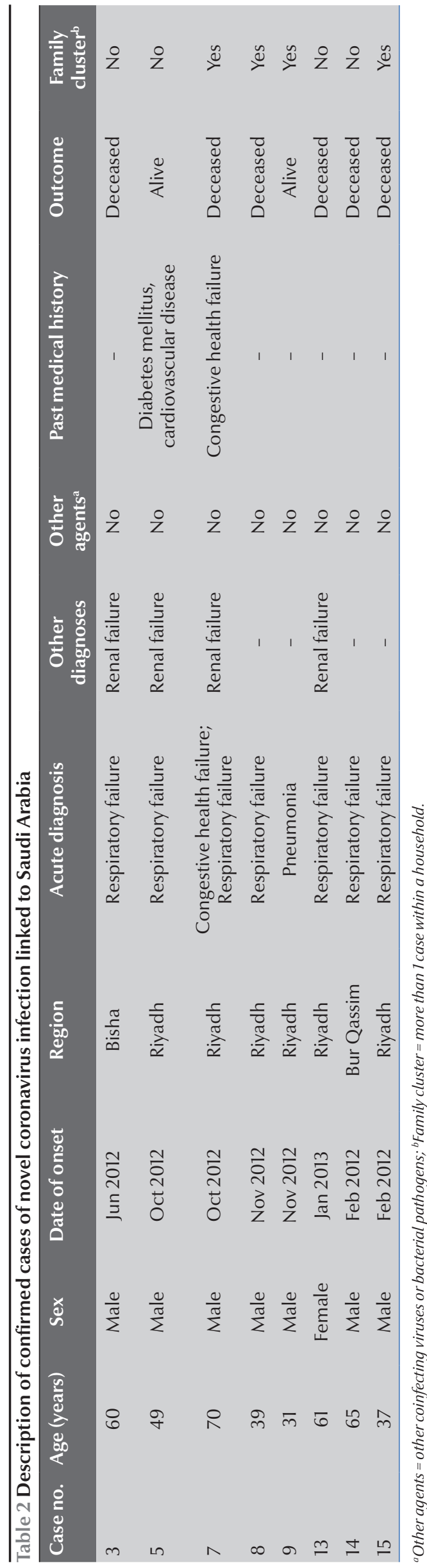

influenza-like illness, cholera and foodborne illness, meningococcal disease, yellow fever, viral haemorrhagic fever, polio and plague [8]. The WHO collaborating Centre for Mass Gatherings Medicine in Saudi Arabia is the repository for data from each Hajj event.

\section{Novel coronavirus}

Hajj 2012 was scheduled to start on 24 October, a month after the first report of the discovery of $\mathrm{nCoV}$. Infectious disease risks were updated and reviewed by the National Scientific Committee on 27 September 2012. Evidence of $\mathrm{nCoV}$ prevalence in the region was then limited to 2 confirmed cases. Although both cases resembled SARS pneumonias - fulminant disease in previously healthy adults - there were no symptomatic secondary cases among 64 health-care workers exposed to case 2 in the UK [9] and none were identified at Jeddah or Bisha hospitals where there was exposure to the first case. Family members of both cases remained well. Neither the WHO nor the Saudi Arabian government found compelling reasons to restrict access to the Hajj based on concerns about $\mathrm{nCoV}$.

\section{Hajj studies and collaborations}

To further evaluate the prevalence of $\mathrm{nCoV}$ in Saudi Arabia, enhanced surveillance was undertaken at the 2012 Hajj. Individuals who met the Hajj case definition for suspected infection (Table 1) were evaluated by health-care staff and swab specimens were collected and referred to a regional $\mathrm{MOH}$ laboratory for testing. Public health staff also monitored health-care facilities and all hospitals in the cities of Mecca and Medina for cases of severe respiratory infection. In addition, Saudi Arabia enabled other governments and nongovernmental organizations to collect specimens and analyse data on pilgrims returning home.

Sample size continues to be an issue for studies of communicable disease risks at the Hajj; organizing investigations based on a representative selection of pilgrims is particularly challenging given the intensity of the event and a denominator of 2.5 to 3 million people. Nonetheless, the Saudi Arabian $\mathrm{MOH}$ confirmed that admissions of respiratory cases to Hajj hospitals had been within the expected range for the 2012 Hajj. Respiratory tract swabs of hospitalized patients - 190 from Medina hospitals and another 86 from Mecca hospitals - tested negative for $\mathrm{nCoV}$ molecular targets, as did swabs from 154 pilgrims tested on return home to France [10]. More recently the Saudi Arabian $\mathrm{MOH}$, through its leadership of the newly established collaborating Centre for Mass Gatherings Medicine, will conduct cross-sectional and longitudinal studies on $\mathrm{nCoV}$ and other respiratory tract infections for surveillance, prevention and control. 


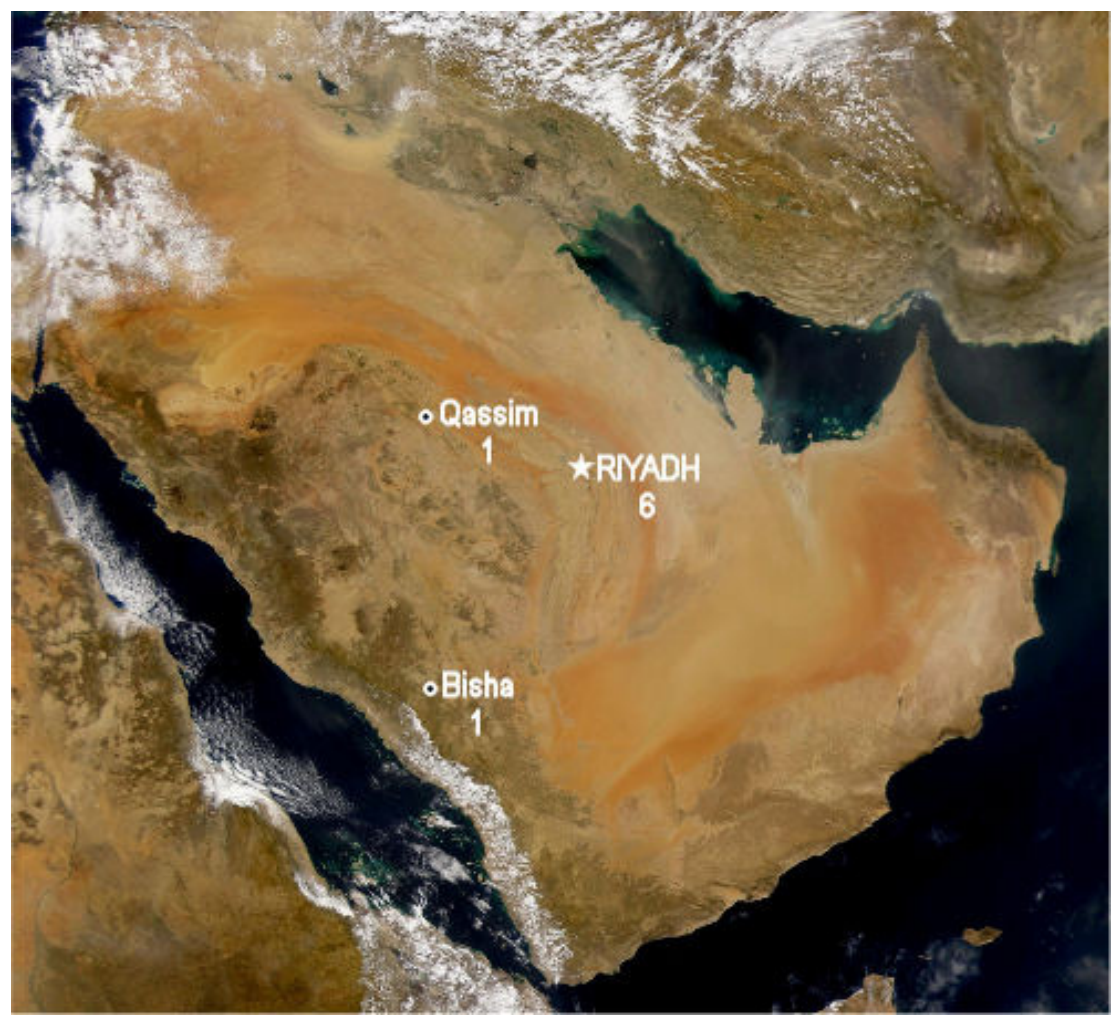

Figure 1 Map of Saudi Arabia showing the location of cases

\section{Summary}

The first report of a virulent $\mathrm{nCoV}$ in September 2012 has been followed by an extraordinary convergence of global expertise focused on this agent and on the countries of the Eastern Mediterranean Region that have been linked to it. Ten years ago it was another virulent coronavirus - SARS - that compelled the first truly international effort aimed at containing an incipient virus pandemic. That legacy is evident now; scientific collaborations have produced full genome sequences, laboratory tests to quickly diagnose infection and a body of knowledge that supports a technology-driven search for an animal reservoir. Perhaps the most important legacy of SARS is the International Health Regulations 2005, with new rules to compel rapid, coordinated case reporting and enable an informed evaluation of global risks [6]. This information is now disseminated to a global audience in real time. Whether $\mathrm{nCoV}$ disappears suddenly, as did the SARS coronavirus in 2003, remains to be seen. To date, there is limited evidence to support a pandemic risk, although transmission to close contacts is now established with certainty. Whether we are watching an epidemic in progress remains to be seen. Collaborations and partnerships with local disease experts have been slow to evolve, yet they remain essential if we are to have a better understanding of the epidemiology of $\mathrm{nCoV}$.

\section{References}

1. Zaki AM et al. Isolation of a novel coronavirus from a man with pneumonia in Saudi Arabia. New England Journal of Medicine, 2012, 367:1814-1820.

2. Novel coronavirus-Saudi Arabia: human isolate. ProMed, 2012, archive number 1302733:20.

3. Corman VM et al. Detection of a novel human coronavirus by real-time reverse-transcription polymerase chain reaction. Eurosurveillance, 2012, 17(39):pii 20285.

4. Bermingham A et al. Severe respiratory illness caused by a novel coronavirus, in a patient transferred to the United Kingdom from the Middle East, September 2012. Eurosurveillance, 2012, 17(40):pii 20290.

5. Albarrak AM et al. Recovery from severe novel coronavirus infection. Saudi Medical Journal, 2012, 33:1265-1269.

6. International health regulations (2005), 2nd ed. Geneva, World Health Organization, 2005.
7. Novel coronavirus 2012 in the UK: situation as at 19 February 2013. Health Protection Report, 2013, 7(8).

8. Al-Tawfiq JA, Memish ZA. The Hajj: updated health hazards and current recommendations for 2012. Eurosurveillance, 2012, 17(41):pii 20295.

9. Pebody RG et al. The United Kingdom public health response to an imported laboratory confirmed case of a novel coronavirus in September 2012. Eurosurveillance, 2012, 17(40):pii 20292.

10. Gautret P et al. Lack of nasal carriage of novel corona virus (HCoV-EMC) in French Hajj pilgrims returning from the Hajj 2012, despite a high rate of respiratory symptoms. Clinical Microbiology and Infection, 2013, Feb 11 (doi: 10.1111/14690691.12174). 